\title{
Pengaruh Return on Equity, Current Ratio dan Pertumbuhan Perusahaan terhadap Dividend Payout Ratio (Studi Empiris pada Perusahaan \\ Manufaktur Sektor Industri Barang Konsumsi yang Terdaftar Di Bursa Efek Indonesia)
}

\author{
*Moh. Fatkhur Rohman, Enny Istanti \\ Jurusan Akuntansi Fakultas Ekonomi dan Bisnis \\ Universitas Bhayangkara Surabaya, Indonesia
}

DOI: 10.46821/equity.v1i1.206

\begin{abstract}
ABSTRAK
Penelitian ini bertujuan untuk mengetahui pengaruh Return on Equity, Current Ratio, Pertumbuhan Perusahaan terhadap Dividend Payout Ratio pada perusahaan manufaktur sektor industri barang konsumsi yang terdaftar di BEI periode tahun 2016-2020, baik secara simultan, parsial, maupun dominan. Penelitian ini menggunakan metode penelitian kuantitatif. Sampel penelitian sebanyak 13 perusahaan manufaktur sektor industri barang konsumsi yang diperoleh dengan teknik pengambilan sampel yaitu purposive sampling. Analisis data dilakukan dengan analisis regresi linear berganda. Hasil penelitian menunjukkan bahwa secara parsial variabel Current Ratio dan Pertumbuhan Perusahaan tidak berpengaruh, sedangkan variabel Return on Equity berpengaruh terhadap Dividend Payout Ratio. Secara simultan variabel Return on Equity, Current Ratio dan pertumbuhan perusahaan berpengaruh terhadap Dividend Payout Ratio.
\end{abstract}

Kata kunci: $\quad$ Current Ratio (CR), Dividend Payout Ratio, Return on Equity (ROE), dan Pertumbuhan Perusahaan (Assets Growth)

\begin{abstract}
This study aims to determine the effect of Return on Equity, Current Ratio, Company Growth on Dividend Payout Ratio in consumer goods industrial manufacturing companies listed on the Indonesia Stock Exchange for the 2016-2020 period, either simultaneously, partially, or dominantly. This study uses quantitative research methods. The research sample was 13 manufacturing companies in the consumer goods industry sector which was obtained by using a sampling technique, namely purposive sampling. Data analysis was performed by multiple linear regression analysis. The results showed that partially the Current Ratio and Company Growth variables had no effect, while the Return On Equity variable had an effect on the Dividend Payout Ratio. Simultaneously the variables Return On Equity, Current Ratio and company growth affect the Dividend Payout Ratio.
\end{abstract}

Keywords: Current Ratio (CR), Dividend Payout Ratio, Return on Equity (ROE), and Assets Growth

*Corresponding Author:

Email: rohmanfatkhur1002@gmail.com 
PENDAHULUAN

Pada era globalisasi saat ini kemajuan ilmu pengetahuan dan teknologi menyebabkan kegiatan perekonomian dunia mengalami perkembangan yang sangat pesat. Menyebarnya berita mengenai akan diberlakukannya Masyarakat Ekonomi Asean (MEA) serta pemberlakuan MEA semakin mendukung luasnya kesempatan berbisnis lintas Negara di kawasan ASEAN. Hal ini akan berdampak pada perkembangan bisnis dan pasar modal, dengan kata lain, terintegrasi pasar modal ASEAN akan meningkatkan peran-peran pasar modal dalam pembangunan ekonomi Negara-Negara ASEAN. Perkembangan dunia usaha semakin menuntut perusahaan berpacu untuk mengatasi persaingan yang semakin ketat dan kompleks, sehingga perusahaan dituntut harus mampu melaksanakan pengelolaan secara efektif dan efisien agar dapat mencapai tujuan yang diharapkan. (Istanti, 2020,1).

Pentingnya peranan pasar modal ini karena pasar modal merupakan sumber pendanaan jangka panjang bagi korporasi dan untuk memperoleh keuntungan bagi investor. Investor mempunyai tujuan utama dalam menanamkan dananya kedalam perusahaan yaitu untuk mencari pendapatan atau tingkat kembalian investasi (return) baik berupa pendapatan dividen (dividend yield) maupun pendapatan dari selisih harga jual saham terhadap harga belinya (capital gain).

Investor umumnya menginginkan pembagian dividen yang relatif stabil, sehingga mengurangi ketidak pastian investor dalam menanamkan dananya kedalam perusahaan. Perusahaan yang akan membagikan dividen dihadapkan pada berbagai macam pertimbangan antara lain perlunya menahan sebagian laba untuk re-investasi yang mungkin lebih menguntungkan, kebutuhan dana perusahaan, likuiditas perusahaan, target tertentu yang berhubungan dengan rasio pembayaran dividen dan faktor lain yang berhubungan dengan kebijakan dividen.

Permasalahan yang sering timbul dalam pembagian dividen wajib diperhatikan oleh para investor maupun perusahaan yang akan membayarkan dividennya. Jika investor mengharapkan pembagian dividen guna meningkatkan kesejahteraannya, maka perusahaan juga berkewajiban untuk memberikan kesejahteraan pula kepada para pemegang sahamnya. Hal tersebut menarik untuk dibahas ketika suatu kebijakan dividen dijadikan sebagai suatu tindakan yang 2 diharapkan mampu untuk memenuhi tujuan para pemegang sahamnya dan disisi lain diharapkan juga kebijakan dividen tersebut tidak menghambat laju pertumbuhan perusahaan (Lilik dan Kurnia, 2016:2).

Faktor-faktor yang mempengaruhi pembayaran dividen adalah Return on Equity, Current Ratio dan pertumbuhan perusahaan. Bertitik tolak dari faktorfaktor tersebut menunjukkan bahwa variabel-variabel independen yang dapat mempengaruhi Dividend Payout Ratio dapat diidentifikasi sebagai berikut: Return on Equity $\left(\mathrm{X}_{1}\right)$, Current Ratio $\left(\mathrm{X}_{2}\right)$, dan Pertumbuhan perusahaan $\left(\mathrm{X}_{3}\right)$. Sedangkan 
Dividend Payout Ratio (DPR) sebagai variabel dependen (Y) yang merupakan persentase dividen sebagai tujuan yang diharapkan investor.

Menurut (Kasmir, 2016) Return On Equity merupakan rasio yang digunakan untuk mengukur laba bersih setelah pajak dan modal sendiri. Menurut Zakia (2017) apabila Return on Equity yang diperoleh perusahaan semakin tinggi maka akan semakin tinggi pula dividen yang diperoleh oleh pemegang saham. Tingkat Return On Equity pada perusahaan manufaktur sektor industri barang konsumsi cenderung mengalami penurunan. Hal ini mengidentifikasikan pertanda buruk karena apabila Return on Equity mengalami penurunan maka akan berdampak pada penurunan pembayaran dividen yang diberikan kepada investor.

Menurut (Kasmir, 2016) Current Ratio merupakan rasio untuk mengukur kemampuan perusahaan dalam membayar kewajiban jangka pendek atau utang yang secara jatuh tempo pada saat ditagih dengan keseluruhan. Dengan kata lain, berapa banyak aktiva lancar yang tersedia untuk menutupi keajiban jangka pendek atau hutang yang segera jatuh tempo.Menurut Lie dan Osesoga (2020) semakin tinggi current ratio suatu perusahaan menunjukkan bahwa perusahaan mampu melunasi kewajiban jangka pendeknya dengan menggunakan aset lancarnya. Dengan kata lain, semakin besar Current Ratio maka akan meningkatkan pembayaran dividen. Tingkat current ratio pada perusahaan menufaktur sektor industri barang konsumsi cenderung mengalami peningkatan. Hal tersebut akan berpengaruh terhadap pembagian dividen karena apabila Current Ratio perusahaan semakin tinggi maka pembayaran dividen akan semakin besar.

Menurut (Akhamadi, 2021) pertumbuhan perusahaan (Assets Growth) merupakan kenaikan sales (penjualan), earning after tax (EAT), laba per lembar saham, dividen per lembar saham dan harga pasar per lembar saham yang mengambarkan kemampuan perusahaan dalam mempertahankan posisi usahanya..

Menurut Iswara (2017) asset growth menunjukkan pertumbuhan aset dimana aset merupakan aktiva yang digunakan untuk aktivitas operasional perusahaan. Peningkatan aset yang di ikuti peningkatan hasil operasi akan semakin menambah kepercayaan pihak luar terhadap perusahaan.sehingga seorang manajer harus membuat kebijakan dividen (dividend payou ratio) yang menghasilkan keseimbangan antara dividen yang dibagikan dan laba untuk operasional perusahaan. Tingkat pertumbuhan perusahaan pada perusahaan menufaktur sektor industri barang konsumsi cenderung mengalami peningkatan. Hal tersebut akan berpengaruh terhadap pembagian dividen karena apabila tingkat pertumbuhan perusahaan semakin tinggi maka perusahaan cenderung menahan pendapatanya untuk masa depan perusahaan sehingga akan mengurangi pembagian dividen kepada pemegang saham.

Menurut (Hery, 2018) Dividend Payout Ratio merupakan rasio yang menunjukkan hasil perbandingan antara dividen tunai dengan laba perlembar saham. Rasio ini menggambarkan jumlah laba dari setiap lembar saham yang dialokasikan dalam bentuk dividen. pembayaran dividen pada perusahaan 
manufaktur sektor industri barang konsumsi yang terdaftar di Bursa Efek Indonesia (BEI) dari tahun 2016-2020 cenderung mengalami fluktuatif dan mengindikasikan adanya jumlah dividen per lembar saham yang dibayarkan setaiap tahunnya tidak sama. Para manajemen perusahaan lebih mudah dan menjaga dan berusaha meningkatkan nilai perusahaanya karena dengan membagikan dividen akan menarik investor baru agar melakukan aktivitas investasinya sekaligus mempertahankan investor lama.

\section{LANDASAN TEORI}

\section{Return On Equity}

Menurut (Kasmir, 2016) Return on Equity merupakan rasio untuk mengukur laba bersih sesudah pajak dengan modal sendiri . Rasio ini menunjukkan efisiensi penggunaan modal sendiri. Semakin tinggi Return on Equity, maka semakin baik. Artinya posisi pemilik perusahaan semakin kuat. Sebaliknya apabila Return on Equity rendah, maka semakin buruk. Artinya posisi pemilik perusahaan semakin lemah.

Menurut (Fahmi, 2016) Return on Equity disebut juga dengan laba atas equity atau perputaran total aset. Rasio ini mengkaji sejauh mana suatu perusahaan mempergunakan sumber daya yang dimiliki oleh perusahaan untuk mampu memberikan laba atas ekuitas.

Menurut (Hanafi, 2016) Return on Equity adalah Rasio yang mengukur kemampuan perusahaan menghasilkan laba berdasarkan modal saham tertentu. Rasio ini merupakan ukuran profitabilitas dari sudut pandang pemegang saham. Berdasarkan pengertian diatas dapat disimpulkan bahwa Return on Equity adalah pengukuran efektivitas perusahaan untuk mendapatkan keuntungan dengan menggunakan modal perusahaan yang dimilikinya, kemampuan perusahaan dalam menghasilkan laba tidak hanya diukur menurut besar kecilnya laba yang dihasilkan, tapi dengan modal sendiri yang telah dikeluarkan untuk menghasilkan laba tersebut. Menurut (Kasmir, 2016) perhitungan Return on Equity dapat dilakukan dengan rumus sebagai berikut :

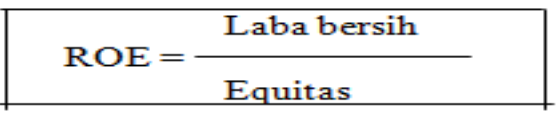

\section{Current Ratio}

Menurut (Hery, 2016) Current Ratio adalah rasio yang digunakan untuk mengukur kemampuan perusahaan dalam memenuhi kewajiban pendeknya yang segera jatuh tempo dengan menggunakan total aset lancar yang tersedia.

Menurut (Kasmir, 2016) Current Ratio adalah rasio untuk mengukur kemampuan perusahaan dalam membayar kewajiban jangka pendek atau hutang yang akan segera jatuh tempo pada saat ditagih secara keseluruhan. Dengan kata lain, seberapa banyak aktiva lancar yang tersedia untuk menutupi kewajiban jangka pendek yang segera jatuh tempo. 
Menurut (Satriana, 2017) Current Ratio adalah perbandingan antara total aktiva lancar dengan total kewajiban lancar. Rasio ini digunakan untuk mengukur keadaan likuditas suatu perusahaan sebagai petunjuk untuk mengetahui kemampuan perusahaan dalam memenuhi kewajiban jangka pendeknya dengan total aktiva lancar yang dimiliki. Berdasarkan pengertian diatas maka dapat disimpulkan bahwa rasio Current Ratio merupakan gambaran kemampuan perusahaan dalam membayar kewajiban jangka pendeknya yang segera jatuh tempo dengan dengan menggunakan aktiva yang dimiliki.

Menurut (Satriana, 2017) perhitungan Current Ratio dapat dihitung dengan rumus sebagai berikut :

$$
\text { Current ratio }=\frac{\text { Aktiva lancar }}{\text { Hutang lancar }} \times 100 \%
$$

\section{Pertumbuhan Perusahaan.}

Menurut Nurhasanah (2016:17) pertumbuhan perusahaan dinyatakan sebagai pertumbuhan total aktiva dimana pertumbuhan masa lalu akan mengambarkan profitabilitas yang akan datang dan pertumbuhan yang akan datang.

Menurut Amalia (2016) pertumbuhan perusahaan merupakan kemampuan suatu perusahaan dalam meningkatkan aset, ekuitas, laba atau penjualan perusahaan.

Menurut (Kasmir, 2016) rasio pertumbuhan merupakan rasio yang menggambarkan kemampuan perusahaan mempertahankan posisi ekonominya ditengah pertumbuhan perekonomian dan sektor usahanya. Berdasarkan pengertian diatas dapat disimpulkan bahwa rasio pertumbuhan merupakan gambaran bagaimana kemampuan suatu perusahaan meningkatkan aset dan mempertahankan posisi ekonominya ditegah pertumbuhan perekonomian dan sektor usahanya selama satu periode.

Menurut Halim (2016) perhitungan tingkat pertumbuhan perusahaan dapat menggunakan rumus sebagai berikut :

$$
\text { Total aset } 1-\text { Total aset } \mathrm{t}-1
$$

$$
\text { Growth }=\frac{\text { Total aset } \mathrm{t}-1}{\text { Total }}
$$

\section{Dividend Payou Ratio}

Menurut (Hery, 2016) Dividend Payout Ratio (DPR) merupakan rasio yang menunjukan hasil perbandingan antara dividen tunai perlembar saham dengan laba perlembar saham. Rasio ini menggambarkan jumlah laba dari setiap lembar saham yang dialokasikan dalam bentuk dividen”. Dengan begitu rasio ini digunakan sebagai salah satu proksi (pendekatan) dalam menetapkan kebijakan dividen yaitu saat mengambil keputusan. 
Menurut (Musthafa, 2017) Dividend Payout Ratio (DPR) adalah perbandingan antara dividen yang dibayarkan dengan laba bersih. Semakin tinggi Dividend Payout Ratio, akan menguntungkan bagi investor selaku pemegang saham, sebaliknya akan memperlemah internal financial perusahaan. Dari pengertian diatas dapat disimpulkan bahwa Dividend Payout Ratio adalah rasio perbandingan antara dividen yang dibayarkan dengan laba perlembar saham.

Menurut (Hery, 2016) perhitungan Divdend Payout Ratio dapat menggunakan rumus sebagai berikut:

$$
\text { Dividend payout ratio }=\frac{\text { Dividend Per Share }}{\text { Earning Per Share }}
$$

\section{Hipotesis}

1. Bahwa variabel Return on Equity, Current Ratio dan Pertumbuhan Perusahaan secara simultan berpengaruh signifikan terhadap Dividend Payout Ratio.

2. Bahwa variabel Return on Equity, Current Ratio dan Pertumbuhan Perusahaan secara parsial berpengaruh signifikan terhadap Dividend Payout Ratio.

3. Bahwa variabel Return on Equity secara dominan berpengaruh signifikan terhadap Dividend Payout Ratio.

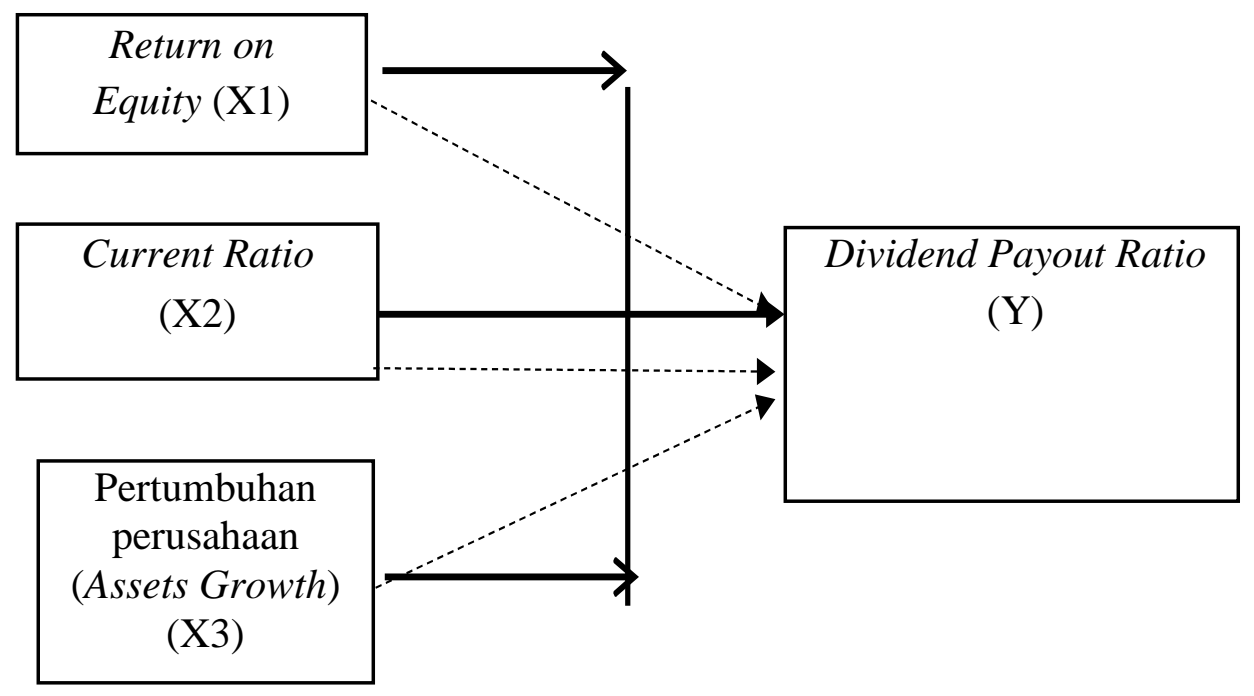

Gambar 1. Kerangka Konseptual

\section{METODE PENELITIAN}

\section{Populasi}

Populasi dalam penelitian ini adalah perusahaan manufaktur sektor industri barang konsumsi yang terdaftar di Bursa Efek Indonesia (BEI) yang memiliki jumlah populasi 51 perusahaan tetapi tidak semua populasi ini akan menjadi objek penelitian. 


\section{Sampel}

Dalam penelitian ini menggunakan 13 sampel perusahaan sektor manufaktur yang terdaftar di Bursa Efek Indonesia (BEI), menggunakan 65 sampel laporan keuangan selama 5 periode, yaitu dari tahun 2016 sampai tahun 2020.

\section{HASIL DAN PEMBAHASAN}

\section{Uji Autokolerasi}

Berdasarkan hasil uji autokolerasi pada Tabel 1 diketahui bahwa nilai durbinWatson sebesar 1,698. Untuk mengetahui terjadinya autokolersi atau tidak, perlu diketahui nilai dl, du, 4-dl, dan 4-du terlebih dahulu dengan melihat tabel DurbinWatson. Berdasarkan tabel Durbin-Watson dengan k (variabel bebas) sebanyak 3 dan $\mathrm{n}$ (jumlah data) sebanyak 65 diketahui bahwa nilai dl sebesar 1,346 dan nilai du sebesar 1,534 sehingga diperoleh nilai 4-dl sebesar 2,654 dan nilai 4-du sebesar 2,466. Hal ini menunjukkan bahwa data berada di $\mathrm{U} \leq \mathrm{DW} \leq 4$-du (1,534 $\leq 1,698 \leq 2,466$ ) maka dapat disimpulkan bahwa data yang digunakan dalam penelitian ini tidak terjadi autokolerasi.

\section{Analisis Linear Berganda}

Persamaan regresi linear berganda :

$\mathrm{Y}=4182,028+0,239(\mathrm{ROE})+0,004(\mathrm{CR})-0,379($ Growth $)$

Berdasarkan persamaan Tabel 2, maka dapat diartikan bahwa konstanta sebesar 4182,028 menunjukkan bahwa apabila variabel Return on Equity, Current Ratio dan Pertumbuhan Perusahaan dianggap sama dengan nol maka variabel Dividend Payout Ratio sebesar 4182,028. Return on Equity sebesar 0,239 menunjukan bahwa apabila Return on Equity mengalami kenaikan satu satuan maka Dividend Payout Ratio mengalami kenaikan sebesar 0,239. Current Ratio sebesar 0,004 menunjukkan bahwa apabila Current Ratio mengalami kenaikan satu satuan maka Dividend Payout Ratio mengalami kenaikan sebesar 0,004. Pertumbuhan perusahaan (Growth) sebesar -0,379 menunjukkan bahwa apabila pertumbuhan perusahaan (Growth) mengalami kenaikan satu satuan maka Dividend Payout Ratio mengalami penurunan sebesar 0,379 .

Tabel 1. Hasil Uji Autokolerasi

\begin{tabular}{lrcccc}
\multicolumn{6}{c}{ Model Summary $^{\mathrm{b}}$} \\
\hline Model & $\mathrm{R}$ & R Square & Adjusted R Square & $\begin{array}{c}\text { Std. Error of the } \\
\text { Estimate }\end{array}$ & Durbin-Watson \\
\hline 1 & $.421^{\mathrm{a}}$ & .177 & .137 & 2402.75086 & 1.698 \\
\hline
\end{tabular}

a. Predictors: (Constant), GROWTH, ROE, CR

b. Dependent Variable: DPR

Sumber: Data Diolah (2021) 
Uji F

Vol. 2 No. 12021

Berdasarkan tabel 3 diperoleh nilai signifikan 0,007 $\leq 0,05$ dan Fhitung 4,377 $\geq \mathrm{F}$ tabel 2,75 sehingga dapat disimpukan bahwa variabel Return on Equity, Curren Ratio dan pertumbuhan perusahaan berpengaruh terhadap Dividend Payout Ratio.

Tabel 2 Hasil Analisis Linear Berganda

\begin{tabular}{|c|c|c|c|c|c|c|c|}
\hline \multirow[b]{3}{*}{ Model } & \multicolumn{5}{|c|}{ Coefficients $^{\mathbf{a}}$} & \multirow{2}{*}{\multicolumn{2}{|c|}{$\begin{array}{l}\text { Collinearity } \\
\text { Statistics }\end{array}$}} \\
\hline & \multicolumn{2}{|c|}{$\begin{array}{l}\text { Unstandardized } \\
\text { Coefficients }\end{array}$} & $\begin{array}{l}\text { Standardized } \\
\text { Coefficients }\end{array}$ & \multirow[b]{2}{*}{$\mathrm{T}$} & \multirow[b]{2}{*}{ Sig. } & & \\
\hline & B & Std. Error & Beta & & & $\begin{array}{l}\text { Toleran } \\
\text { ce }\end{array}$ & VIF \\
\hline $\begin{array}{ll}1 & \text { (Constan } \\
\text { t) }\end{array}$ & 4182.028 & 779.192 & & 5.367 & .000 & & \\
\hline ROE & .239 & .095 & .310 & 2.510 & .015 & .884 & 1.132 \\
\hline $\mathrm{CR}$ & .004 & .016 & .034 & .272 & .787 & .857 & 1.167 \\
\hline $\begin{array}{l}\text { GROWT } \\
\mathrm{H}\end{array}$ & -.379 & .193 & -.241 & -1.961 & .054 & .895 & 1.117 \\
\hline
\end{tabular}

a. Dependent Variable: DPR

Sumber: Data Diolah (2021)

Tabel 3. Hasil Uji F

\begin{tabular}{llrrrrr}
\multicolumn{7}{c}{ ANOVA $^{\mathrm{a}}$} \\
\hline Model & & Sum of Squares & \multicolumn{1}{c}{ Df } & Mean Square & \multicolumn{1}{c}{ F } & Sig. \\
\hline 1 & Regression & 75816574.590 & 3 & 25272191.530 & 4.377 & $.007^{\mathrm{b}}$ \\
& Residual & 352165913.300 & 61 & 5773211.694 & & \\
& Total & 427982487.900 & 64 & & &
\end{tabular}

a. Dependent Variable: DPR

b. Predictors: (Constant), GROWTH, ROE, CR

Sumber: Data Diolah (2021)

Tabel 4. Hasil Uji t

\begin{tabular}{|c|c|c|c|c|c|c|c|c|}
\hline \multicolumn{9}{|c|}{ Coefficients $^{\mathrm{a}}$} \\
\hline & & \multicolumn{2}{|c|}{$\begin{array}{c}\text { Unstandardized } \\
\text { Coefficients }\end{array}$} & \multirow{2}{*}{$\begin{array}{c}\begin{array}{c}\text { Standardized } \\
\text { Coefficients }\end{array} \\
\text { Beta }\end{array}$} & \multirow[b]{2}{*}{$\mathrm{T}$} & \multirow[b]{2}{*}{ Sig. } & \multicolumn{2}{|c|}{$\begin{array}{c}\text { Collinearity } \\
\text { Statistics }\end{array}$} \\
\hline \multicolumn{2}{|c|}{ Model } & B & Std. Error & & & & $\begin{array}{c}\text { Toleranc } \\
\mathrm{e}\end{array}$ & VIF \\
\hline 1 & (Constant) & $\begin{array}{r}4182.02 \\
8\end{array}$ & 779.192 & & 5.367 & .000 & & \\
\hline & ROE & .239 & .095 & .310 & 2.510 & .015 & .884 & 1.132 \\
\hline & $\mathrm{CR}$ & .004 & .016 & .034 & .272 & .787 & .857 & 1.167 \\
\hline & $\begin{array}{l}\text { GROWT } \\
\mathrm{H}\end{array}$ & -.379 & .193 & -.241 & -1.961 & .054 & .895 & 1.117 \\
\hline
\end{tabular}

Sumber: Data Diolah (2021) 
Tabel 5. Hasil Uji Dominan

\begin{tabular}{|c|c|c|c|c|c|c|c|}
\hline \multirow[b]{3}{*}{ Model } & \multicolumn{5}{|c|}{ Coefficients ${ }^{\mathrm{a}}$} & & \\
\hline & \multicolumn{2}{|c|}{$\begin{array}{l}\text { Unstandardized } \\
\text { Coefficients }\end{array}$} & \multirow{2}{*}{$\begin{array}{c}\text { Standardized } \\
\text { Coefficients }\end{array}$} & \multirow[b]{2}{*}{$\mathrm{T}$} & \multirow[b]{2}{*}{ Sig. } & \multicolumn{2}{|c|}{$\begin{array}{c}\text { Collinearity } \\
\text { Statistics }\end{array}$} \\
\hline & B & Std. Error & & & & Tolerance & VIF \\
\hline $\begin{array}{ll}1 & \text { (Constant })\end{array}$ & 4182.028 & 779.192 & & 5.367 & .000 & & \\
\hline ROE & .239 & .095 & .310 & 2.510 & .015 & .884 & 1.132 \\
\hline CR & .004 & .016 & .034 & .272 & .787 & .857 & 1.167 \\
\hline GROWTH & -.379 & .193 & -.241 & -1.961 & .054 & .895 & 1.117 \\
\hline
\end{tabular}

a. Dependent Variable: DPR

Sumber: Data Diolah (2021)

\section{Uji t}

Berdasarkan tabel 4 dapat diperoleh kesimpulan sebagai berikut :

1. Hasil uji menunjukkan variabel Return on Equity mempunyai nilai signifikansi $0,015 \leq 0,05$ dan nilai thitung 2,510 $\geq$ ttabel 1,670 maka dapat disimpulkan bahwa variabel Return On Equity berpengaruh signifikan terhadap Dividend Payout Ratio.

2. Variabel Current Ratio mempunyai nilai signifikansi sebesar 0,272 $\geq 0,05$ dan thitung 0,272 $\leq$ ttabel1,670 sehingga dapat disimpukan bahwa variabel Current Ratio tidak berpengaruh dan tidak signifikan terhadap Dividend Payout Ratio.

Pertumbuhan perusahaan (Growth) mempunyai nilai signifikansi sebesar $0,054 \geq 0,05$ dan thitung $-1,961 \leq$ ttabel1,670 sehingga dapat disimpulkan bahwa variabel pertumbuhan perusahaan (Growth) tidak berpengaruh dan tidak signifikan terhadap Dividend Payout Ratio.

\section{Uji Dominan}

Berdasarkan tabel 5 terlihat bahwa nilai koefisien beta terbesar adalah variabel Return on Equity (X1) yaiu sebesar 0,310 artinya variabel Return on Equity memberikan pengaruh yang dominan terhadap Dividend Payout Ratio. Sedangkan variabel Current Ratio mempunyai nilai koefisien beta sebesar 0,034 dan pertumbuhan perusahaan (Growth) mempunyai koefisien beta sebesar -0,241.

\section{Pembahasan}

\section{Pengaruh Return on Equity terhadap Dividend Payout Ratio}

Berdasarkan hasil pengujian secara parsial (uji t) bahwa untuk variabel Return on Equity (X1) diketahui $\mathrm{t}$ hitung sebesar 2,510 $\geq \mathrm{t}$ tabel sebesar 1,670 dengan tingkat signifikan sebesar $0,015 \leq 0,05$. Hal ini berarti H0 ditolak dan H1, maka dapat diambil kesimpulan bahwa variabel Return on Equity berpengaruh positif dan signifikan terhadap Dividend Payout Ratio. Hal ini berarti semakin tinggi pofit maka akan semakin tinggi juga pembagian dividen perusahaan. Hasil ini sesuai dengan hipotesis yang diajukan sebelumnya, bahwa Return on Equity secara parsial berpengaruh signifikan terhadap Dividend Payout Ratiopada 
perusahaan manufaktur sektor industri barang konsumsi yang terdaftar di Bursa Efek Indonesia tahun 2016-2020. Hasil penelitian ini sejalan dengan dengan penelitian yang dilakukan oleh Yulian Bayu Ganar (2018) yang menyatakan bahwa Return on Equity berpengaruh signifikan terhadap Dividend Payout Ratio (Y).

\section{Pengaruh Current Ratio Terhadap Dividend Payout Ratio}

Berdasarkan hasil pengujian secara pasial (uji t), bahwa untuk variabel Current Ratio diketahui thitung sebesar $0,272 \leq$ ttabel sebesar 1,670 dengan tingkat signifikasi $0,787 \geq 0,05$. Maka dapat disimpulkan bahwa secara parsial variabel Current Ratio) tidak berpengaruh signifikan terhadap Dividend Payout Ratio. Hal ini berarti perusahaan memfokuskan likuditas jangka pendeknya untuk operasionalnya dan memenuhi kewajiban jangka pendeknya dibandingkan dengan memfokuskan untuk pembayaran dividen. Hasil ini tidak sesuai dengan hipotesis yang diajukan sebelumnya, bahwa Current Ratio secara parsial berpengaruh signifikan terhadap Dividend Payout Ratio pada perusahaan manufaktur sektor industri barang konsumsi yang terdaftar di Bursa Efek Indonesia tahun 20162020. Hasil ini didukung dengan penelitian yang dilakukan Elana Devi dan Mispiyanti (2020), bahwa Current Ratio tidak berpengaruh terhadap Dividend Payout Ratio.

\section{Pengaruh pertumbuhan perusahaan (Growth) Terhadap Dividend Payout Ratio}

Berdasarkan hasil pengujian secara parsial (uj t), bahwa variabel pertumbuhan perusahaan (X3) diketahui nilai $t$ hitung sebesar $-1,961 \leq \mathrm{t}$ tabel 1,670 dengan tingkat signifikan $0,054 \geq 0,05$. Maka dapat disimpulkan bahwa secara parsial variabel pertumbuhan perusahaan tidak berpengaruh dan tidak signifikan terhadap Dividend Payout Ratio Hasil ini tidak sesuai dengan hipotesis yang diajukan sebelumnya, bahwa pertumbuhan perusahaan secara parsial berpengaruh signifikan terhadap Dividend Payout Ratio pada perusahaan manufaktur sektor industri barang konsumsi yang terdaftar di Bursa Efek Indonesia tahun 20162020. Hal ini karena adanya biaya tersendiri untuk penambahan aset perusahaan sehingga tinggi rendahnya tingkat pertumbuhan perusahaan tidak mempengaruhi tingkat dividend payout ratio. Asumsi ini sejalan dengan penelitian yang dilakukan oleh (Elana Devi, 2020) yang menyatakan bahwa setiap perusahaan memiliki dana tersendiri (laba ditahan) yang nantinya akan digunakan untuk pembayaran dividen, sehingga perusahaan yang kinerjanya baik dan seimbang dapat mengatur keuangan untuk tjuan yang berbeda seperti untuk kebutuhan perusahaan dan pembayaran dividen. Hasil ini didukung dengan penelitian yang dilakukan (Eka Setiajatnika, 2018) bahwa pertumbuhan perusahaan tidak tidak berpengaruh signifikan terhadap dividend payout ratio.Tingkat pertumbuhan perusahaan yang tinggi bukan jaminan bagi suatu perusahaan nantinya akan membagikan membagikan dividen kepada para pemegang saham atau insvestor. 
Perusahaan yang memiliki tingkat pertumbuhan perusahaan yang tinggi tentu akan mempertimbangkan apakah laba yang diperoleh perusahaan akan dibagikan sebagai dividen atau ditahan sebagai laba ditahan, karena pada umumnya perusahaan perusahaan lebih memilih laba ditahan yang akan digunakan untuk modal perusahaan, kegiatan operasional, pengembangan usaha serta kegiatan investasi.

\section{SIMPULAN}

Berdasarkan hasil penelitian ini dapat ditarik kesimpulan bahwasannya variabel Return on Equity, Current Ratio dan Pertumbuhan Perusahaan secara simultan berpengaruh signifikan terhadap Dividend Payout Ratio. Variabel Return on Equity secara parsial berpengaruh signifikan terhadap Dividend Payout Ratio. Variabel Current Ratio secara parsial tidak berpengaruh dan tidak signifikan terhadap Dividend Payout Ratio. Variabel Pertumbuhan Perusahaan secara parsial tidak berpengaruh dan tidak signifikan terhadap Dividend Payout Ratio.

\section{DAFTAR PUSTAKA}

Ade Febriani, M. S. (2019). Pengaruh Firm Size dan Growth Oportunity terhadap Return On Asset dan Dividen Payout Ratio. Jurnal Ilmiah Magister Manajemen.

Akhamadi, S. E. (2021). Faktor Mediasi Profitabilitas dan Sturktur Modal (Uji Signifikansi Pada Hubungan Antara Pertumbuhan Perusahaan Dengan Nilai Perusahaan. Media Sains Indonesia.

Anwar, M. (2019). Dasar-Dasar Manajemen Keuangan Perusahaan . Jakarta : Kencana.

Bayu, Y. (2018). Pengaruh Current Rati, Net Profit Margin, Return On Equity dan Earning Per Share terhadap Dividend Payout Ratio pada perusahaan yang terdaftar di Bursa Efek Indonesia. Jurnal Disrupsi Bisnis.

Darmawan. (2018). Manajemen Keuangan (Memahami Kebijakan Dividen Teori dan Praktiknya di Indonesia. Yogyakarta : FEBI UIN Sunan Kalijaga.

Eka Setiajatnika, K. I. (2018). Pengaruh Return On Assets, Debt to Equity Ratio dan Assets Growth terhadap Dividend Payout Ratio pada perusahaan manufaktur yang terdaftar di Bursa Efek Indonesia. Jurnal Soshum Insentif.

Elana Devi, M. (2020). Pengaruh Profitabilitas, Likuiditas, Pertumbuhan Perusahaan dan Ukuran Perusahaan Terhadap Kebijakan Dividen. Jurnal STIE Putra Bangsa.

Erwin Dyah Astawinetu, S. H. (2020). Manajemen Keuangan (Teori dan Praktek). Surabaya : Scopindo Media Pustaka. 
Fahmi, I. (2016). Pengantar Manajemen Keuangan. Bandung: CV. ALFABETA .

Hanafi, M. M. (2016). Analisis Laporan Keuangan. Yogyakarta: UPP STIM YKPN.

Handini, E. D. (2020). Manajemen Keuangan (Teori Dan Praktek). Surabaya: Scopindo Media Pustaka.

Hery. (2016). Analisis Laporan Keuangan . Yogyakarta : UPP STIM YKPM.

Hery. (2018). Analisis Laporan Keuangan (Integrated and Comprehensive). Jakarta : PT.Gramedia .

Istanti, E. (2020). Evaluasi Prosedur Pengendalian Intern atas Piutang Usaha pada PT Sps (Depo Gedangan). Akuntansi'45, 1(1), 1-7. https://univ45sby.ac.id/ejournal/index.php/akuntansi45/article/view/64

Irfani, A. S. (2020). Manajemen Keuangan dan Bisnis. Jakarta: PT. Gramedia Pustaka Utama .

Jatmiko, D. P. (2017). Pengantar Manajemen Keuangan. Yogyakarta: Diandra Kreatif.

Jumingan. (2017). Analisis Laporan Keuangan. Jakarta: PT. Bumi Aksara.

Kasmir. (2016). Pengantar Manajemen Keuangan. Jakarta: Prenada Media.

Martha, C. J. (2018). Pengaruh Current Ratio, Debt to Equity Ratio, Earning Per Share, Return On Assets dan Assets Growth Terhadap Dividen Payout Ratio pada perusahaan LQ-45 yang terdaftar di Bursa Efek Indonesia. Jurnal KURS.

Musthafa. (2017). Manajemen Keuangan. Yogyakarta: CV. Andi Offset.

Pratama, R. (2020). Pengantar Manajemen. Yogyakarta: Deepublish.

Siti. Aisya, dkk. (2020). Manajemen Keuangan. Yayasan Kita Menulis.

Sugiono. (2019). Metode Kuantitatif, Kualitatif dan R\&D. Bandung: CV. ALFABETA .

Sulaiman, Sarmo, dkk. (2019). Pengaruh Earning After Tax, Current Ratio, Debt to Equity Ratio Terhadap Dividen Payot Ratio. 